\title{
Yeast cells as a feed supplement for cattle 3. New yeast preparations for cows in the first period of lactation
}

\section{J. A. Strzetelski, J. Kowalczyk ${ }^{1}$, K. Bilik, Teofila Stasiniewicz, M. Soroka and Barbara Niwińska}

\author{
Research Institute of Animal Production, \\ Department of Animal Nutrition and Physiology \\ 32-083 Balice, Poland \\ 'The Kielanowski Institute of Animal Physiology and Nutrition, \\ Polish Academy of Sciences \\ 05-110 Jabionna, Poland
}

(Received 30 April 1995; accepted 12 January 1996)

\begin{abstract}
A study was conducted on 28 cows between the third weck preceding and fourteenth week after calving. The cows were divided into 4 groups of 7 . The animals in the control group (C) were fed a basic ration consisting of maize and beet top silage, meadow hay, soyabean oilmeal, concentrate for extra milk production and mineral mixtures according to the INRA system. This ration was supplemented for the experimental groups with Yea-Sacc preparation $(Y)$ or with preparations containing baker's yeast Saccharomyces cerevisiae G1 produced according to a cell-engineering method (X) or Saccharomyces carlsbergensis brewery strain SK-1 (S).

Average milk production during the experimental period in the respective groups was, in $\mathrm{kg}$ : $26.7-\mathrm{C} ; 28.2-\mathrm{X}$ and $\mathrm{S} ; 27.7-\mathrm{Y}$; the milk-fat content: $4.05 ; 4.01 ; 3.99$ and $4.29 \%$ and protein content, $3.01 ; 2.98 ; 3.09$ and $3.15 \%$. The persistence of milk yield after the peak of lactation was greater in cows receiving a yeast supplement than in the cows of the control group.
\end{abstract}

KEY WORDS: yeast preparation, lactating cows, milk yield

\section{INTRODUCTION}

The results of numerous experiments and practical trials on dairy cows have shown that supplementing the diet with Yea-Sacc preparation containing 
Saccharomyces cerevisiae 1026 produced by Alltech Biotechnology Center stimulates milk yicld and improves milk composition (Dildey, 1988; Williams, 1989; Wohlt et al., 1991; Wallace and Newbold, 1992; Cooley, 1993; Skórko-Sajko et al., 1993). Recent studies have concentrated on new yeast strains and fungi that increase the effects of ruminant nutrition (Fondevila et al., 1990; Williams and Newbold, 1990; Moore and Headon, 1992; Wallace and Newbold, 1992; Dawson, 1993). Strzetelski et al. (1995a,b) obtained yeast preparations containing different strains of Saccharomyces carlsbergensis yeast and demonstrated their suitability for feeding calves and fattening bulls.

The aim of the present experiment was to assess the effectiveness of new yeast supplements containing Saccharomyces cerevisiae G1 and Saccharomyces carlsbergensis SK-1 in dairy cow nutrition.

\section{MATERIAL AND METHODS}

\section{Animals and experimental design}

The experiment was carried out on 28 Black-and-White Lowland cows divided into 4 groups of 7 animals allotted to the groups by the analog method at 3 weeks before calving, taking into account maximum milk yield at the peak of the previous lactation, number of lactations ( 2 to 4 ) and 30 to $70 \%$ of hf blood proportion. Allocation to the groups was completed within 2 months.

The cows were fed individually at a controlled feed intake. The concentrate mixture consisted of $(\%)$ : ground barley, 35 ; wheat bran, 15 ; ground triticale, 13 ; soyabean oilmeal, 21 ; dehydrated whole barley crop with undersown lucerne, 10; meat-and-bone meal, 2; mineral mixture', 4. Daily rations were establishcd according to the INRA (IZ, 1993) using INRAtion 2.03 software (1993). The cows were given maize silage, beet top silage, meadow hay, soyabean oilmeal and concentrate mixture. Rations for experimental groups were supplemented with $10 \mathrm{~g} / \mathrm{cow} /$ day of the respective yeast preparation. During the 3 wecks before calving up to day 6 after calving, the cows received rations according their maximal milk production during the preceding lactation, afterwards the rations were corrected according to predicted maximal milk yield calculated after calving (IZ, 1993).

\footnotetext{
' - mineral mixture composition (\%): $12.5 \mathrm{CaHPO}_{4} \cdot 2 \mathrm{H}_{2} \mathrm{O}$; limestone, 12.5; premix B, 12.5; commercial mineral mixture MMB, 62.5 .

$1 \mathrm{~kg}$ of mineral mixture contained, $\mathrm{g}: \mathrm{P}-46, \mathrm{Ca}-156, \mathrm{Na}-80, \mathrm{Mg}-29, \mathrm{Zn}-3.42, \mathrm{Cu}-0.98$, $\mathrm{Co}-0.02, \mathrm{Mn}-2.54, \mathrm{Fe}-0.325, \mathrm{~J}-0.012$
} 
The cows of the control group (C) were fed a basal diet without yeast supplement. Rations for the experimental groups were supplemented with Yea-Sacc preparation containing Saccharomyces cerevisiae $1026(\mathrm{Y})$ or one of two of own yeast supplements containing Saccharomyces carlsbergensis brewery strain SK-1 (S) or baker's yeast Saccharomyces cerevisiae strain G-1 (X). The feeding trial was terminated after 14 weeks of lactation. Daily milk yield and fat and protein content in 3-day bulked samples were determined.

\section{Yeast supplements}

Yea-Sacc supplement was obtained from Alltech Biotechnology Center Agency in Warsaw. Agar cultures of Saccharomyces carlsbergensis SK-1 and Saccharomys cerevisiae G1 were obtained from the Institute of Biotechnology of the Agriculture and Food Industry in Warsaw. The yeast inoculum was incubated for $48 \mathrm{~h}$ at $30^{\circ} \mathrm{C}$. The pure laboratory culture was obtained by initial cultivation on YPG followed by cultivation on diluted 1:10 molasses wort supplemented with minerals. The period of incubation in both cases was $24 \mathrm{~h}$ at $30^{\circ} \mathrm{C}$. Cultivation of yeast was carried out at first on a laboratory scale in a 4.51 fermenter (Chemap Type LF7) and afterwards in a 1001 macro fermenter (New Brunswick) for $16 \mathrm{~h}$ in both cases. The carbon and energy source for yeast was molasses wort containing $50 \%$ of polarimetrically determined sugar. The wort was supplemented with $98 \mathrm{~g}$ ammonium sulphate, $13.6 \mathrm{~g}$ dibasic ammonium phosphate and $5.6 \mathrm{~g}$ magnesium sulphate. Cultivation was carried out at $30^{\circ} \mathrm{C}$, $\mathrm{pH}=5.2$ and $\mathrm{pO}_{2}=5$ to $10 \%$. Dry yeast preparations were obtained by spinning yeast wort and drying of the biomass by fluidization, except the preparation for group $\mathrm{X}$, which was dried by fluidization of the biomass mixed with barley bran $(1: 0.75)$ as a carrier.

\section{Analysis and calculations}

The density of yeast cultures administered to animals was determined in a Burker chamber by counting the number of yeast cells in samples fixed in formalin-glicerol and expressed as the number of cells per gram of preparation.

Proximate analysis of feed samples was carried out using conventional methods (AOAC, 1975). The nutritive value of feeds was estimated according to the INRA system (1988) using Polish computer software INWAR 1.0 (1993). Fat and protein content in milk was determined using Milko-Scan 133B equipment.

The obtained data were subjected to variance analysis with multiple range test using Statgraphics Plus 6.0 software (1992). 


\section{RESULTS}

Average yeast culture density ( $\mathrm{n} \times 10^{6}$ cells/g) was 85,107 and 517 in groups $\mathrm{Y}$, $S$ and $X$, respectively. Nutrients content in feeds and feeding value of the diet are given in the Table 1 . Feed intake in animals of the control group (C) was slightly less (about $3 \%$ ) and of group $\mathrm{Y}$ more (about $2 \%$ ) than in the groups $\mathrm{S}$ and $\mathrm{X}$, however, these differences were not significant $(P>0.05)$. Average daily feed intake for all animals was $(\mathrm{kg} /$ day): maize silage -23.7 ; beet top silage -5.0 ; meadow hay -3.6 ; soyabean oilmeal -0.8 and concentrate mixture -8.0 (Table 1). Daily intake of nutrients in cows of group C was: $16.8 \mathrm{~kg} \mathrm{DM}$; 2816 g CP; 1709 g PDI (PDIE - PDIN =-54) and 14.3 UFL. There were no significant differences between the groups in nutrients and feed intake $(P>0.05)$, although supplementing diets with a yeast preparation slightly increased nutrients intake, on average by: DM, 3\%; CP, 4\%; PDI, 1.5 and UFL, 3 .

TABLE 1

Composition of feeds and nutrients content

\begin{tabular}{|c|c|c|c|c|c|}
\hline Feed & $\mathrm{DM}$ & Ash & $\mathrm{CP}$ & $\mathrm{CF}$ & Fat \\
\hline Barley ground & 88.02 & 2.12 & 10.91 & 4.14 & 2.43 \\
\hline Wheat bran & 86.24 & 3.30 & 13.60 & 5.37 & 4.33 \\
\hline Triticale ground & 86.83 & 2.61 & 13.30 & 3.16 & 1.77 \\
\hline Soyabean oilmeal & 87.99 & 6.66 & 43.08 & 7.17 & 2.35 \\
\hline \multicolumn{6}{|c|}{ Whole barley crop dehydrated } \\
\hline with undersown lucerne & 90.14 & 5.78 & 12.21 & 19.22 & 3.36 \\
\hline Meat-and-bone meal & 93.80 & 28.20 & 38.60 & - & 24.50 \\
\hline Concentrate mixture $^{1}$ & 87.80 & 4.12 & 18.63 & 6.08 & 3.05 \\
\hline Maize silage $^{2}$ & 22.95 & 1.48 & 1.89 & 5.09 & 1.35 \\
\hline Beet top silage ${ }^{3}$ & 19.26 & 3.47 & 2.84 & 4.31 & 1.08 \\
\hline Meadow hay ${ }^{4}$ & 84.33 & 4.65 & 12.68 & 29.36 & 1.98 \\
\hline
\end{tabular}

in $1 \mathrm{~kg}$ DM according to INRA system (1988):

1 - 128 g PDI (PDIE - PDIN =-16), $1.08 \mathrm{UFL}$

2 - $51 \mathrm{~g}$ PDI (PDIE - PDIN $=10), 0.89$ UFL

3 - 83 g PDI (PDIE - PDIN $=-7$ ), 0.58 UFL

${ }^{4}$ - 87 g PDI (PDIE - PDIN $\left.=-7\right), 0.73 \mathrm{UFL}$

Milk yield in the cows of the experimental groups was 5, 6 and $4 \%$ higher in group $\mathrm{X}, \mathrm{S}$ and $\mathrm{Y}$, respectively, than in the control group, however, these differences were not statistically significant (Table 2). The persistence of milk yield after the peak of lactation in the control group was lower (77\%) than in the experimental groups: $85 \%$ in groups $\mathrm{X}$ and $\mathrm{S}, 90.5 \%$ in group $\mathrm{Y}$ (Figure 1). 
TABLE 2

Milk yield and composition

\begin{tabular}{lrrrrr}
\hline \multirow{2}{*}{ Item } & \multicolumn{5}{c}{ Group } \\
\cline { 2 - 6 } & $\mathrm{C}$ & $\mathrm{X}$ & $\mathrm{S}$ & $\mathrm{Y}$ & $\mathrm{SE}$ \\
\hline Milk yield, kg/day $_{\text {initial }^{1}}$ & 19.46 & 20.85 & 21.23 & 20.79 & 1.94 \\
$\quad$ final $^{2}$ & 23.46 & 27.20 & 26.60 & 25.32 & 4.88 \\
$\quad$ average $_{\text {FCM }}$ & 26.72 & 28.18 & 28.22 & 27.71 & 3.77 \\
Milk fat, \% & 26.92 & 28.15 & 28.06 & 28.75 & 3.44 \\
Milk protein, \% & 4.05 & 4.01 & 3.99 & 4.28 & 0.30 \\
\hline
\end{tabular}

${ }^{1}$ - average of first day lactation

${ }^{2}$ - average of 14-th week lactation

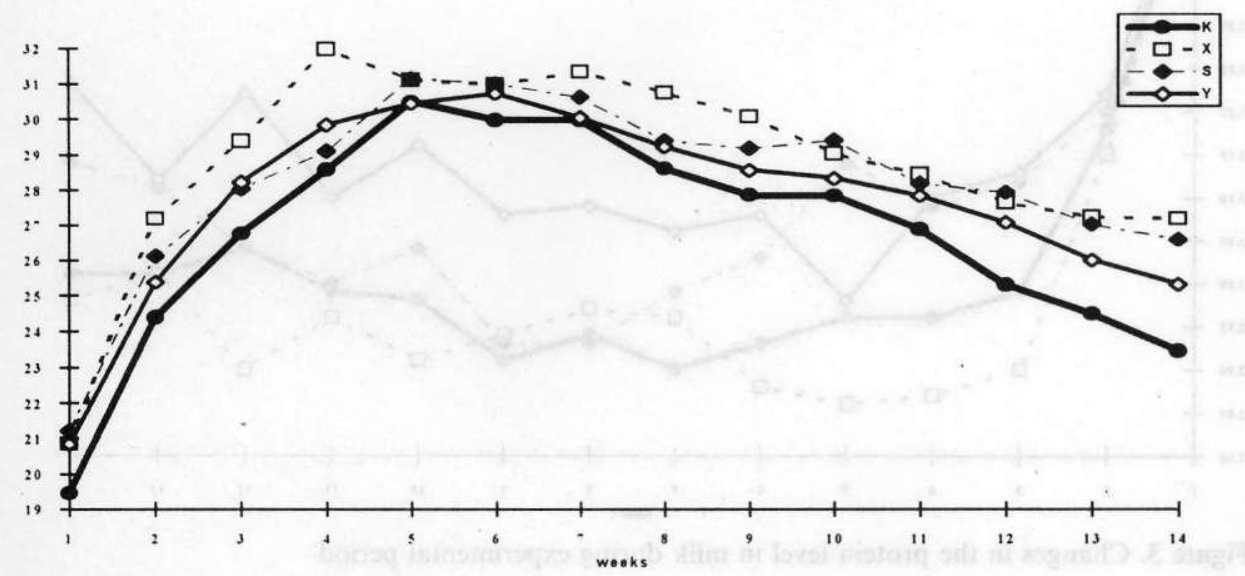

Figure 1. Changes in the daily milk production during experimental period

Milk fat and protein contents in group Y were slightly, but not significantly, higher during the entire experimental period than in the remaining groups (Figures 2 and 3). Supplementing the basal diet with yeast did not affect nutrients utilization $(\mathrm{P}>0.05)$, however, the cows of the control group needed somewhat (3\%) more nutrients for production of $1 \mathrm{~kg}$ milk (0.63 kg DM, $105 \mathrm{~g} \mathrm{CP}, 64 \mathrm{~g}$ PDI and 0.53 UFL) than animals of the experimental groups. All cows used about $0.32 \mathrm{~kg}$ concentrate, including compensating mixture, for $1 \mathrm{~kg}$ milk produced. 


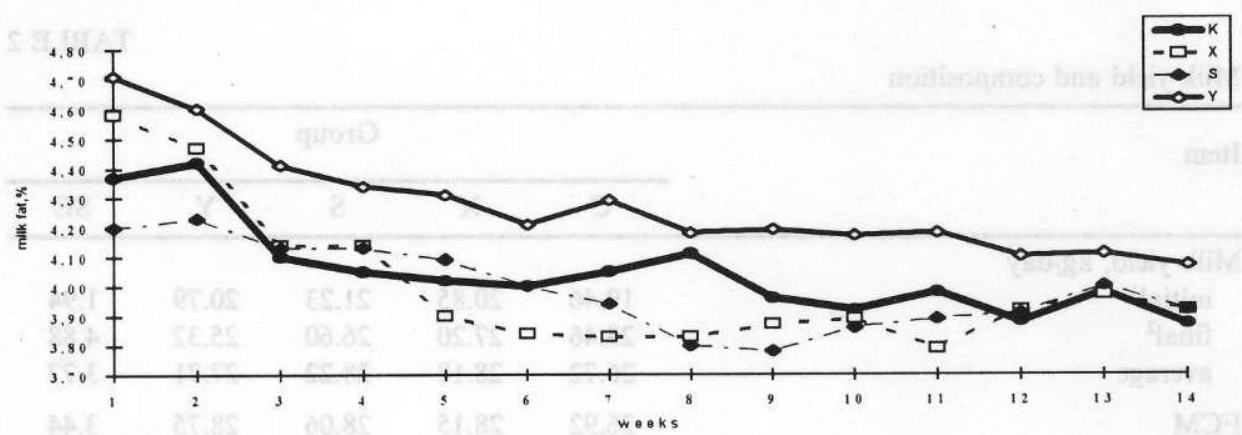

Figure 2. Changes in the fat level in milk during experimental period

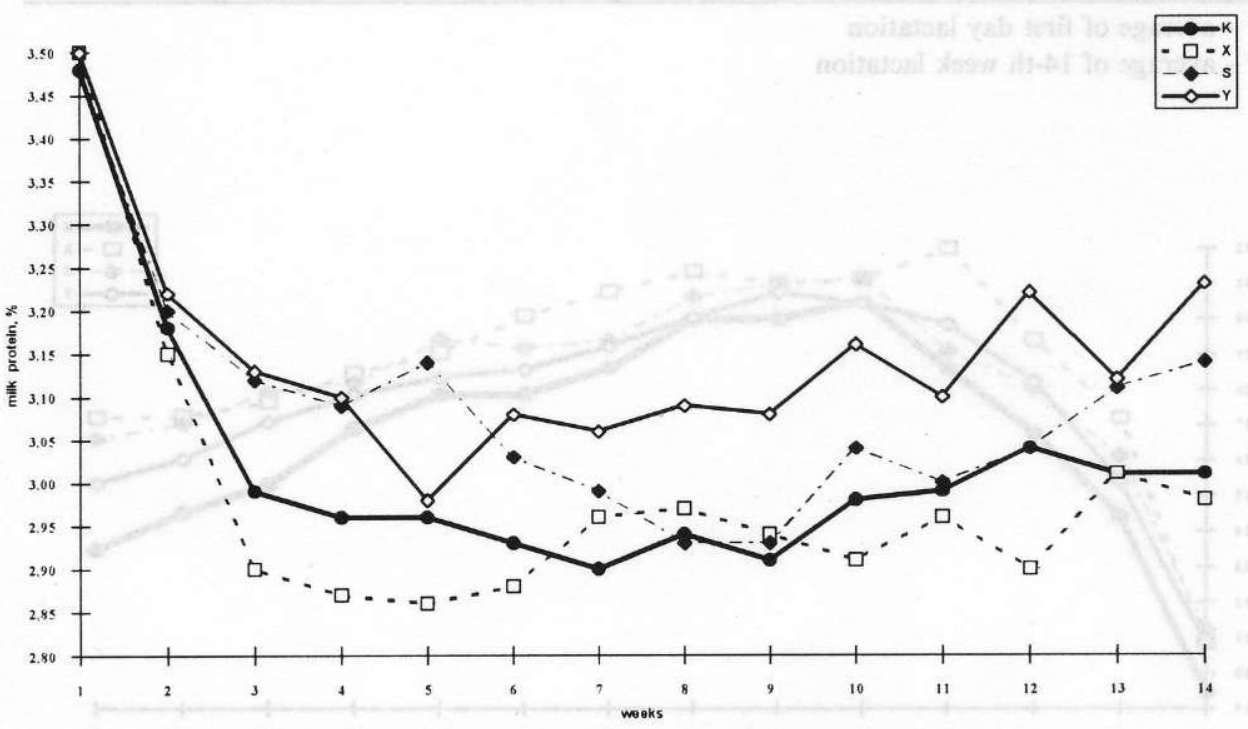

Figure 3. Changes in the protein level in milk during experimental period

\section{DISCUSSION}

Results obtained in this experiment confirmed the finding of other authors that Yea-Sacc stimulates milk yield in cows (Dildey, 1988; Harris and Lobo, 1988; Williams, 1989; Harris and Webb, 1990; Williams and Newbold, 1990; Wallace and Newbold, 1992; Skórko-Sajko et al., 1993). One of the interesting results is that supplementing diets for cows with Saccharomyces carlsbergensis SK-1 affected not only milk production but also tended to increase protein and decrease fat content in milk. May be this supplement, similarly as Saccharomyces 
cerevisiae 1026 present in Yea-Sacc, can lead to increased protein and amino acid delivery and advantageous changes in amino acid profile in protein reaching the duodenum (Erasmus, 1991; Erasmus et al., 1992).

The increased fat content in milk in the group receiving the Yea-Sacc supplement could result from a change in the rumen fermentation pattern that increased acetic acid production (Harrison et al., 1988). In our earlier studies on digestion in the rumen (Strzetelski et al., 1995b), a high ratio of $\mathrm{C}_{2}: \mathrm{C}_{3}(4.4)$ was found in bulls fed diets supplemented with Yea-Sacc. Williams et al. (1991) and Piva et al. (1993) found a similar increase of the $\mathrm{C}_{2}: \mathrm{C}_{3}$ ratio in the rumen of dairy cows and increased fat content in milk after supplementing the diet with the Yea-Sacc preparation.

The higher milk yield after supplementing diets with yeast preparations was probably caused by higher DM intake compared with the control group (Williams and Newbold, 1990; Wohlt et al., 1991). The advantageous effect of yeast preparation on milk production, which was marked during all periods of the experiment, could also be a result of a better established fermentation pattern in the rumen compared with that in control animals (Harrison et al., 1988; Adams et al., 1995). This conclusion is supported by the higher persistence of milk yield after peak of lactation in our experiment.

\section{REFERENCES}

Adams A.L., Harris B.Jr., Van Horn H.H., Wilcox C.J.. 1995. Effect of varying forage types on milk production responses to whole cottonseeds, tallow, and yeast. J. Dairy Sci. 78, 573-581

AOAC, 1975. Association of an Official Analytical Chemists, Official Methods of Analysis, 12th Ed., Washington DC

Cooley B.A., 1993. Effects of supplemental yeast culture to dairy cows rations. J. Dairy Sci. 76, Suppl. 1, 315

Dawson K.A., 1993. Yeast culture as a fecd supplements for ruminants: Mode of action and future application. J. Anim. Sci. 71. Suppl. 1, 280

Dildey D.D., 1988. Getting paid for milk quality: Improving milk composition. In: T.P. Lyons (Editor). Biotechnology in Fecd Industry. Alltch Technical Publications. Nicholasville, Kentucky, pp. 45-66

Erasmus L.J., 1991. The importance of duodenal amino acid profiles for dairy cows and significance of changes in these profiles following the use of Yea-Sacc 1026. In: T.P. Lyons (Editor). Biotechnology in Feed Industry. Alltech Technical Publications. Nicholasville, Kentucky, pp. $33-50$

Erasmus L.J., Botha P.M., Kistner A., 1992. Effect of yeast culture supplement on production. rumen fermentation and duodenal nitrogen flow in dairy cows. J. Dairy Sci. 75, 3056-3065

Fondevila M., Newbold C.J., Hotten P.M., Ørskov E.R., 1990. A note on the effect of Aspergillus oryzae fermentation extract on the rumen fermentation of sheep given straw. Anim. Prod. 51, $422-425$ 
Harris B.Jr., Lobo R., 1988. Feeding yeast culture to lactating cows. J. Dairy Sci. 71, Suppl. 1, 276 Harris B.Jr., Webb D.W., 1990. The effect of feeding a concentrated yeast culture product to lactating dairy cows. J. Dairy Sci. 73. Suppl. 1, 266

Harrison G.A., Hemken R.W., Dawson K.A., Harmon R.J., Barker K.B., 1988. Influence of addition of yeast culture supplement to diets of lactating cows on ruminal fermentation and microbial populations. J, Dairy Sci. 71, 2967-2975

INRA, 1988. Institut National de la Recherche Agronomique, Alimentation des bovins, ovins, caprins (Ed. R. Jarrige), Paris

IZ, 1993. Institute of Zootechnics, Standards of cattle, sheep and goat nutrition (in Polish). Omnitech Press. Warsaw

Moore E., Headon D.R., 1992. Identification of specific yeast strains may be future trend. Feedstuffs, $64,38,13-21$

Piva G., Belladonna S., Fusconi G., Sicbaldi F., 1993. Effect of yeast on dairy cow performance, ruminal fermentation, blood components and mitk manufacturing propertics. J. Dairy Sci. 76, 2717-2722

Skórko-Sajko H., Sajko J., Zalewski W., 1993. The effect of 1026 YEA-SACC in the ration for dairy cows on production and composition of milk. J. Anim. Feed Sci. 2, 159-167

Strzetelski J.A., Ernest T., Maciejewicz-Ryś J., Maciaszek K., Kowalczyk J., Lipiarska E., 1995a. Yeast feed as a feed supplement for cattle. 1. Liquid viable yeast cultures for calves. J. Anim. Feed Sci. 4, 171-181

Strzetelski J.A., Maciejewicz-Ryś J., Kowalczyk J., Niwińska B., Stasiniewicz T., Maciaszek K., 1995b. Yeast cells as a feed for cattle. 2. Effect of liquid yeast cultures on digestive processes in the rumen of bulls. J. Anim. Feed Sci. 4, 287-297

Wallace R.J., Newbold C.J.. 1992. Probiotics for ruminants. In: R. Fuller (Editor). Probiotics the Scientific Basis. Chapman and Hall, London, pp. 316-353

Williams P.E.V., 1989. The use of yeast culture to improve ruminant productivity. In: T.P. Lyons (Editor). Biotechnology in Feed Industry. Alltech Technical Publications. Nicholasville, Kentucky, pp. 65-84

Williams P.E.V., Newbold C.J., 1990. Rumen probiosis: The effect of novel microorganisms on rumen fermentation and ruminant productivity. In: W. Haresing, D.J. $\Lambda$. Cole (Editors). Recent Advances in Animal Nutrition. Butterworths, London, pp. 211-225

Williams P.E.V., Tait C.A.G., Innes G.M., Newbold C.J., 1991. Effect of the inclusion of yeast culture (Saccharomyces cerevisiae plus growth medium) in the diet of dairy cows on milk yield and forage degradation and fermentation patterns in the rumen of steers. J. Anim. Sci. 69, 3016-3026

Wohlt J.E., Finkelstein A.D., Chung C.H., 1991. Yeast culture to improve intake, nutrient digestibility, and performance by dairy cattle during early lactation. J. Dairy Sci. 74, 1395-1400

\section{STRESZCZENIE}

Zastosowanie drożdży jako dodatku paszowego w żywicniu bydla.

3. Nowe preparaty drożdżowe dla krów w pierwszym okresie laktacji

Wpływ dodatków preparatów drożdżowych na efekty produkcyjne badano na 28 krowach rasy ncb podzielonych na 4 grupy po 7 szluk w każdej. Doświadczenie trwalo od 3 tygodnia przed wycieleniem do 14 tygodnia po wycieleniu. Grupa kontrolna (C) otrzmywała dawkę podstawową bez 
preparatu natomiast do dawek dla grup doświadczalnych dodawano preparat Yea-Saac (Y) lub preparaty wyprodukowane według własnej technologii zawierające drożdże piekarnicze Saccharomyces cerevisiae G1 otrzymane metodą inżynierii komórkowej (X) bądź Saccharomyces carlsbergensis szczepu piwowarskiego SK-1 (S).

Średnia produkcja mleka w ciągu całego doświadczenia wynosiła, $\mathrm{kg}: 26,7$ - C; 28,2 - X i S; 27,7 - Y, zawartość thuszczu w mleku wynosiła odpowiednio: 4,05; 4,01; 3,99 i 4,28\%, a białka - 3,01; 2,$98 ; 3,09$ i 3,15\%. U krów otrzymujących dodatki preparatów wytrwałość produkcji mleka po szczycie laktacji była większa niż w grupie kontrolnej. 